\title{
Predictors of the intention to maintain social distancing
}

\author{
Gabriel Horn Iwaya 1 \\ Janaína Gularte Cardoso 23 \\ João Henriques de Sousa Júnior 2 \\ Andrea Valéria Steil ${ }^{1} 4$
}

1 Universidade Federal de Santa Catarina / Graduate Program in Psychology, Florianópolis / SC - Brazil

2 Universidade Federal de Santa Catarina / Graduate Program in Administration, Florianópolis / SC - Brazil

${ }^{3}$ Universidade Federal da Fronteira Sul / Administration Program, Chapecó / SC - Brazil

${ }^{4}$ Universidade Federal de Santa Catarina / Graduate Programs in Engineering and Knowledge Management, Florianópolis / SC - Brazil

This research aimed to develop an Intention to Maintain Social Distancing Scale (IMSDS) based on the Theory of Planned Behavior (TPB). The model establishes that the variables attitudes, subjective norms and perceived behavioral control are predictors of the intention to maintain social distancing (IMSD). The methodological design was an online survey with non-probabilistic sampling. The survey included 786 Brazilian participants, mostly residents of the southern region of the country. The TBP variables explained $85 \%$ of the IMSD variation: subjective norms $(\beta=0.69)$, attitudes $(\beta=0.24)$ and perceived behavioral control $(\beta=0.06)$. These results provide evidence of what are the underlying beliefs that influence the IMSD. This evidence is relevant to public and private organizations in the process of developing strategies to promote and engage the population in adopting the behavior of "maintaining social distancing" in Brazil. In the discussions, the practical implications are presented, pointing out the limitations of the research and the possibilities for future studies on IMSD.

Keywords: COVID-19; intention to maintain social distancing; social distancing.

\section{Preditores da intenção de permanecer em distanciamento social}

A presente pesquisa teve por objetivo desenvolver uma Escala de Intenção de Permanecer em Distanciamento Social (EIPDS) com base na Teoria do Comportamento Planejado (TCP). O modelo teórico estabelece que as variáveis "atitudes", "normas subjetivas" e "controle comportamental percebido" são preditoras da intenção de permanecer em distanciamento social (IPDS). O delineamento metodológico foi o de levantamento online com amostragem não probabilística. A pesquisa contou com 786 participantes brasileiros, majoritariamente residentes da região Sul do país. As variáveis da TCP explicaram $85 \%$ da variação da IPDS: normas subjetivas $(\beta=0,69)$, atitudes $(\beta=0,24)$ e controle comportamental percebido $(\beta=0,07)$. Os resultados evidenciam quais crenças subjacentes exercem influência sobre a formação da IPDS e podem servir às organizações públicas e privadas no processo de desenvolvimento de estratégias de promoção e engajamento da população na adoção do comportamento de "permanecer em distanciamento social" no Brasil. O trabalho apresenta as implicações práticas, as limitações da pesquisa e as possibilidades de estudos futuros sobre a IPDS.

Palavras-chave: COVID-19; intenção de permanecer em distanciamento social; distanciamento social.

\section{Predictores de la intención de permanecer en distanciamiento social}

Esta investigación tuvo como objetivo desarrollar una escala de intención de permanecer en distanciamiento social (EIPDS), con base en la teoría del comportamiento planificado (TCP). El modelo establece que las variables actitudes, normas subjetivas y control conductual percibido son predictoras de la intención de permanecer en distanciamiento social (IPDS). El diseño metodológico fue una encuesta online con muestreo no probabilístico. La encuesta contó con 786 participantes brasileños, en su mayoría residentes de la región sur del país. Las variables TCP explicaron el $85 \%$ de la variación de la IPDS: normas subjetivas $(\beta=0,69)$, actitudes $(\beta=0,24)$ y control conductual percibido $(\beta=0,07)$. Los resultados proporcionan evidencia sobre cuáles son las creencias subyacentes que influyen en la formación de la IPDS. Estas evidencias son relevantes para las organizaciones públicas y privadas en el proceso de desarrollo de estrategias de promoción, que generan el compromiso de la población de adoptar el comportamiento de "permanecer en distanciamiento social" en Brasil. En las discusiones, se presentan las implicaciones prácticas, señalando las limitaciones de la investigación y las posibilidades para futuros estudios sobre IPDS.

Palabras clave: COVID-19; intención de permanecer en distanciamiento social; distanciamiento social.

DOI: http://dx.doi.org/10.1590/0034-761220200177x

Article submitted on April 16, 2020 and accepted on June 08, 2020.

ISSN: 1982-3134@ @ (1)

[Translated version] Note: All quotes in English translated by this article's translator. 


\section{INTRODUCTION}

The pandemic caused by the new coronavirus is considered to be the gravest threat to public health since the first H1N1 influenza virus pandemic in 1918. In the absence of a vaccine for the new coronavirus, which could contain the current disease, various countries have adopted nonpharmacological intervention measures in order to mitigate the transmission of the virus, reducing the levels of contact in the population (Barros-Delben et al., 2020; Chaves \& Bellei, 2020; Lana et al., 2020). Among the adopted interventions, social distancing is being widely used and is associated with government closures of non-essential commerce, schools, universities, etc.

According to the definition proposed by Imperial College, social distancing occurs when "[...] all families reduce contact outside their homes, schools and workplaces by 75\%" (Ferguson et al., 2020, p. 6). However, the effective realization of social distancing is associated with a change in individual behavior patterns, which means that each person needs to understand the importance of this measure in order to be persuaded to adopt a behavior of maintaining social distancing. Studies demonstrate that the success of this persuasion depends on effective communication by leaders of public and private organizations with the population at large (Allcott et al., 2020; Ferguson et al., 2020).

According to the Theory of Planned Behavior (TPB), persuasive communication should consider the effect that certain beliefs held by people exercise on the formation of an intent to perform a specific behavior. The intention is a subjective calculation which encompasses the decision of a person to act and the perception of the force that the person is willing to make to execute a given behavior (Abraham \& Sheeran, 2003). The intention is the last deliberative stage before the performance of a behavior, and is considered its most important cognitive antecedent (Ajzen, 1985, 1991, 2011).

Based on the assumptions of TPB, this study intends to develop an Intention to Maintain Social Distancing Scale (IMSDS). Even though the intention is a universal phenomenon (Ajzen, 2011), its theoretical understanding is strongly based on studies conducted in North America and Europe (Steinmetz, Knappstein, Ajzen, Schmidt, \& Kabst, 2016). Given that context influences the predictive beliefs of intentions (Azjen, 2015), studies should be carried out to understand the dynamics of the development of intentions within various contexts, cultures and moments of time (Leeuw, Valois, Ajzen, \& Schmidt, 2015; Steil, Floriani, Zilli, \& Rubio, 2019).

The development of a scale, with the description of its main psychometric properties, such as validity and precision, is a fundamental step in the measurement and prediction of behavior (Draugalis, Coons, \& Plaza, 2008). This procedure is an important step to ensure that the scale really measures the intended constructs in a reproducible and reliable manner (Cohen, Swerdlik, \& Sturman, 2014). In this manner, the IMSDS developed in this work can be utilized as an instrument to measure the intention of people to adhere to the practice of social distancing in Brazil.

We have determined, with the development of the scale, which beliefs exert greater effects on the intention to maintain social distancing; this information serves public organizations in the elaboration of persuasive communication strategies designed to disseminate the practice of social distancing. The IMSDS developed in this work can also be used to evaluate specific population samples in heterogeneous contexts, considering given segments of the population to evaluate (e.g. poor communities, a given city, college students, etc.). 
According to the TPB, all conscious, deliberate behavior is determined by the formation of an intention (Ajzen, 1985). During the formation of an intention, the subject elaborates a synthesis of possible consequences and the effort needed to behave in a given way, based on underlying beliefs established during his or her lifetime. At the end of this psychological process, the intention is formed and it becomes the last antecedent to the behavior itself. The process of forming the intention, based on a group of beliefs and their relation to behavior, constitutes the central object of the TPB (Ajzen, 1991, Fishbein \& Ajzen, 2010).

The TPB establishes that a person's intention to perform a behavior is influenced by three groups of personal beliefs: attitudes, subjective norms, and perceived behavioral control. Hagger, Hamilton, Ajzen, Bosnjak, and Schmidt (2019) point out that the effectiveness of TPB has been demonstrated by more than two thousand studies and thirty meta-analyses. Given the demonstrated effectiveness of the theoretical model in predicting a wide range of behavior in various populations and contexts, we use TPB in the present work to explain what are the antecedent factors to the behavior of maintaining social distancing.

According to the adopted theoretical model, maintaining social distancing results from a deliberative decision-making process, determined by the formation of an intention. This, in turn, is influenced by attitudes related to social distancing, by subjective norms, and perceived behavioral control (Ajzen, 1985, 1991; Fishbein \& Ajzen, 2010).

The attitudes represent a group of behavioral beliefs expressed in association with the object's attributes. For every behavioral belief a subjective evaluation is also made of the veracity of this association. People are considered to have beliefs related to the measure of social distancing, including the perception of the advantages associated with this behavior (safety, well-being, etc.). The greater the degree of agreement (veracity) with these beliefs, the greater the person's intention will be to adhere to the measure of social distancing (Ajzen, 1991; Fishbein \& Ajzen, 2010; Hagger et al., 2019). Thus, it is established hypothetically that:

H1. Attitudes in relation to social distancing influence the intention to maintain social distancing.

Subjective norms refer to normative beliefs related to the perception of social pressure exerted on a person by his or her peers. These beliefs consider the subjective expectation that people considering references for the individual (e.g. parents, family, friends, spouse, colleagues at work, etc.) will approve or disapprove of a given behavior. The perception of social pressure is also associated with the person's motivation to give in to this pressure (Ajzen, 1991; Fishbein \& Ajzen, 2010; Hagger et al., 2019). People are considered to be in contact with others who, in turn, have their own beliefs in relation to the measure of social distancing. The more that individuals believe that important people in their lives think they should adopt social distancing, the greater their intention will be to maintain this behavior. Thus, it is established that:

H2. Subjective norms influence the intention to maintain social distancing.

The perceived behavioral control is represented by a group of beliefs related to the perception of control factors (facilitators or impediments) associated with the performance of the behavior (Ajzen, 1991). According to Ajzen and Cote (2008), control factors are considered to be: required abilities, the availability or lack of time, money and other resources, etc. Each control belief contributes to the formation of the perceived behavioral control, confirming a sense of individual 
self-efficacy (Fishbein \& Ajzen, 2010; Hagger et al., 2019). The greater the perception of control over maintaining social distancing, the greater the intention will be to adopt this behavior. In this manner, we may establish that:

H3. Perceived behavioral control influences the intention to maintain social distancing.

\section{METHODOLOGY}

This is a quantitative study based on online research, using a cross-section and convenience sampling approach (Shaughnessy, Zechmeister, \& Zechmeister, 2012). The data collection was based on a survey distributed through the social networks (Facebook, Instagram and WhatsApp) during the period from $3 / 31 / 2020$ to $4 / 6 / 2020$ with a sample mostly consisting of residents of the southern region of Brazil.

Two participation criteria were established: the subjects had to be at least 18 years old and belong to the group of people who could choose to maintain social distancing. The beginning of the survey presented the definition of social distancing (Ferguson et al., 2020) and asked people whether they couldn't choose to maintain social distancing (e.g. professionals working in the health industry, supermarkets, pharmacies, gas stations, etc.) which could not answer the survey. To access the survey, participants needed to respond affirmatively to the following question: are you at least 18 years of age and belong to the group of people who can choose to maintain social distancing (yes/no)?

The survey was composed of sociodemographic questions (biological sex, age, completed education, marital status, occupation, income, state and city) related to the TPB construct: attitudes (six items), subjective norms (six items), perceived behavioral control (six items) and the intention to maintain social distancing (six items). The items were developed based on the recommendations of Francis et al. (2004). The study adopted methods of measuring generalized intentions and direct measures, making use of a 7-point Likert scale (totally disagree/totally agree). The items used to measure the variables are listed in Box 1.

\section{BOX 1 ITEMS USED TO MEASURE TPB VARIABLES}

THE THEORY OF PLANNED BEHAVIOR (TPB) VARIABLES
$\begin{aligned} & \text { ITEMS USED TO MEASURE } \\ & \text { ITEMS }\end{aligned}$
ATIMENSION
ATT2 - I Maintaining social distancing for the next few days would make me feel well.
ATT3 - I think that maintaining social distancing for the next few days is the correct choice.
ATT4 - Maintaining social distancing for the next few days will make me feel safe.
ATT5 - I believe that maintaining social distancing for the next few days is an intelligent choice.
ATT6 - Maintaining social distancing for the next few days will make me feel calm.




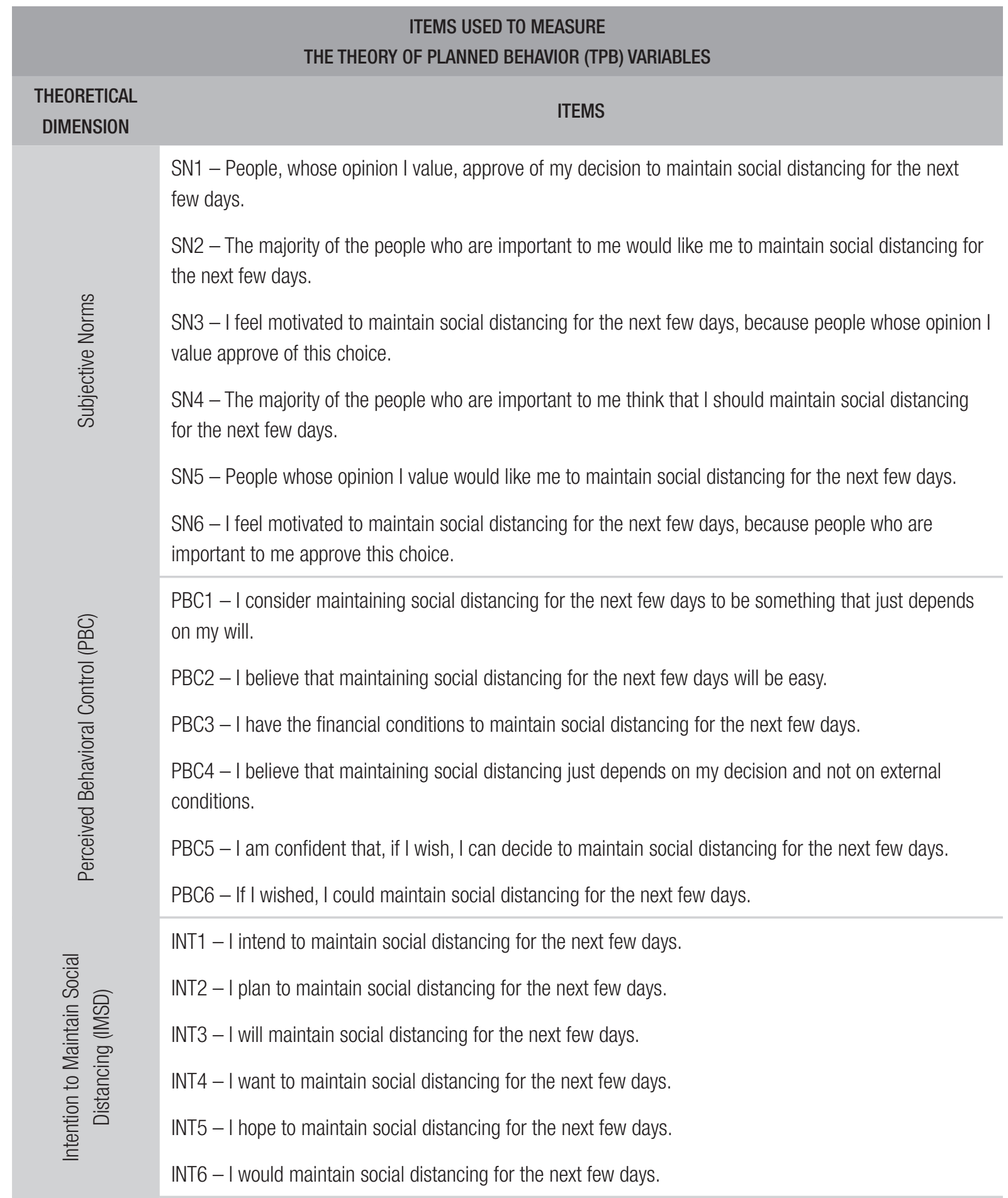

Source: Primary Data (2020).

For the analysis of the internal structure of the IMSDS, we used exploratory factor analysis (EFA), using principal axis factoring and an oblique promax rotation. The factorability of the data was triply evaluated: through visual inspection of a correlation matrix, the Kaiser-Meyer-Olkin index $(\mathrm{KMO}>0.80)$, and Bartlett's sphericity test $(\mathrm{p}<0.05)$. The factors were extracted by a priori criteria, a fixed number of four factors (Damásio, 2012; Hair, Black, Babin, Anderson, \& Tatham, 2009). 
The factor solution obtained was evaluated based on indices of commonality $\left(\mathrm{h}^{2}>0.40\right)$ and factor loadings ( $>0.50)$. Variables with inacceptable indices and/or crossed-loadings were eliminated. The analysis was respecified until we found an appropriate factor structure. Cronbach's alpha $(\alpha>0.70)$ (Hair et al., 2009) was used to evaluate reliability.

As recommended by Ajzen (1991) and Francis et al. (2004), the measurement of the effect of attitudes, subjective norms and PBCs was made through a hierarchical multiple linear regression. The following suppositions were considered: the removal of outliers above three standard deviations; the absence of multicollinearity $(r>0.80)$, observing the values of tolerance $(>0.10)$ and VIF $(<10)$; homoscedasticity, observing the distribution points on the dispersion plot; the independence of residuals, observing the Durbin-Watson test values (acceptable between 1.50 and 2.50); errors are normally distributed, observing the histogram and normal P-P plot of the regression of standardized residuals; and the linear relations between the variables, observing the dispersion plot (Hair et al., 2009).

\section{RESULTS}

This study surveyed 786 participants in 17 Brazilian states, distributed among 109 municipalities. The majority of the participants lived in the southern region of the country (88\%), with the following distribution: Santa Catarina (80\%), Rio Grande do Sul (6\%) and Paraná (2\%). The sociodemographic profile of the participants may be observed in Table 1.

\section{TABLE 1 PROFILE OF THE RESPONDENTS}

\begin{tabular}{|c|c|c|}
\hline \multicolumn{3}{|c|}{ SOCIODEMOGRAPHIC PROFILE OF THE STUDY PARTICIPANTS ( $\mathrm{N=786)}$} \\
\hline Sociodemographic Profile & Frequency & Percentage \\
\hline \multicolumn{3}{|l|}{ Biological sex } \\
\hline Female & 486 & 61.80 \\
\hline Male & 300 & 38.20 \\
\hline \multicolumn{3}{|l|}{ Age group } \\
\hline $18-27$ & 378 & 48.09 \\
\hline $28-37$ & 211 & 26.84 \\
\hline $38-47$ & 104 & 13.23 \\
\hline $48-57$ & 59 & 7.51 \\
\hline $58-67$ & 29 & 3.69 \\
\hline $68-77$ & 5 & 0.64 \\
\hline
\end{tabular}


RAP | Predictors of the intention to maintain social distancing

\begin{tabular}{|c|c|c|}
\hline \multicolumn{3}{|c|}{ SOCIODEMOGRAPHIC PROFILE OF THE STUDY PARTICIPANTS (N=786) } \\
\hline Sociodemographic Profile & Frequency & Percentage \\
\hline \multicolumn{3}{|l|}{ Level of education } \\
\hline Primary education & 1 & 0.13 \\
\hline Secondary education & 322 & 40.97 \\
\hline Higher education & 213 & 27.10 \\
\hline Graduate school (specialization) & 103 & 13.10 \\
\hline Master's & 79 & 10.05 \\
\hline $\mathrm{PhD}$ & 68 & 8.65 \\
\hline \multicolumn{3}{|l|}{ Marital status } \\
\hline Single & 491 & 62.50 \\
\hline Married/Stable Union & 249 & 31.70 \\
\hline Divorced/Separated/Widow(er) & 41 & 5.80 \\
\hline \multicolumn{3}{|l|}{ Occupation } \\
\hline Without permanent employment & 236 & 34.99 \\
\hline Employee of a private organization & 174 & 22.14 \\
\hline Public servant & 170 & 21.63 \\
\hline $\begin{array}{l}\text { Autonomous professional and/or } \\
\text { freelancer }\end{array}$ & 112 & 14.25 \\
\hline $\begin{array}{l}\text { Businessman/Employer of a private } \\
\text { organization }\end{array}$ & 24 & 3.05 \\
\hline Intern in a public or private organization & 12 & 1.53 \\
\hline Retiree & 9 & 1.15 \\
\hline Research Fellow & 7 & 0.89 \\
\hline $\begin{array}{l}\text { Employed in a public/private hybrid } \\
\text { organization }\end{array}$ & 2 & 0.25 \\
\hline Farmer & 1 & 0.15 \\
\hline \multicolumn{3}{|l|}{ Family income } \\
\hline Up to 3 times minimum wage & 306 & 38.90 \\
\hline Between 3 and 6 times minimum wage & 209 & 26.60 \\
\hline Between 6 and 9 times minimum wage & 107 & 13.60 \\
\hline Between 9 and 12 times minimum wage & 72 & 9.20 \\
\hline $\begin{array}{l}\text { Between } 12 \text { and } 15 \text { times minimum } \\
\text { wage }\end{array}$ & 44 & 5.60 \\
\hline Above 15 times minimum wage & 48 & 6.10 \\
\hline
\end{tabular}

Source: Primary Data (2020). 
The profile of the participants is characterized by the prevalence of females $(61.80 \%)$, between the ages of 18 and 27 (48.09\%), who have completed secondary education (40.97\%), are single (62.50\%), and have a family income of up to 3 times the minimum wage $(38,90 \%)$ and do not have permanent employment (35\%).

\subsection{Exploratory factor analysis}

The null hypothesis of the normality of the IMSDS items was rejected by the Kolmogorov-Smirnov test ( $\mathrm{p}<0.000$ ), and this is why we used the principal axis factoring method (Damásio, 2012). The items presented correlations with each other with intensities that did not surpass 0.90 , suggesting the absence of great multicollinearity or overlapping items (Pasquali, 2005). The size of the sample was considered acceptable (above thirty cases per item) (Hair et al., 2009).

The initial factorability analysis of the data was performed through a visual inspection of the correlation matrix, the KMO measurement, and Bartlett's sphericity test, with their being considered acceptable. The inspection of the correlation matrix presented a substantial number of correlations greater than 0.30. The KMO measurement was considered excellent (0.96). Bartlett's test confirmed the appropriateness of the sample for the application of factor analysis $\left[\chi^{2}(276)=\right.$ 21.043.56, $\mathrm{p}<0.00]$.

The exhibition of the coefficients in the factor solution were ordered by the size of their loads, with those below 0.30 not being displayed. Then the loads and commonality of the variables were evaluated. According to Hair et al. (2009), adopting a conservative perspective, items with commonality less than 0.50 can be eliminated.

The flexibilization of the minimum value of commonality is a practice often employed in exploratory studies (Castillo, Macrini, Cheniaux, \& Landeira-Fernandez, 2010; Pereira et al., 2019). In this study, we eliminated items with commonality values less than 0.40 . In the initial factor analysis, the items PBC2 (0.35) and PBC3 (0.31) presented low commonality $\left(\mathrm{h}^{2}>0.40\right)$ and item PBC3 also presented no factor loading in any dimension. In this way, these items were excluded, and the factor analysis was performed again.

The items SN3 and SN6 present cross-loading in the attitude and subjective norm dimensions. The items INT4 and INT5 presented cross-loading in the attitude and intention to maintain social distancing dimensions. After the exclusion of these four items, items ATT1, ATT3, ATT5, PBC6 began to present cross-loading with the items of the intention to maintain social distancing dimension. All ten of these items needed to be removed (ATT1, ATT3, ATT5, SN3, SN6, PBC2, PBC3, PBC6, INT4 and INT5), and they were excluded one at a time.

In addition to the statistical observations which explain the exclusion of the above items, other points may be observed. The excluded items ATT1, ATT3 and ATT5 represented cognitive beliefs in relation to social distancing, in which they considered the adoption of this measure to be something sensible, correct or intelligent. The remaining items which consolidated the attitude dimension were related to affective beliefs (feeling well, calm, safe). Within the scope of TPB, attitudes are composed of affective and cognitive beliefs which are linked to behavior. It is recognized that they are difficult to separate in practice and do not always maintain the exact correspondence between themselves (Schleicher, Watt, \& Greguras, 2004). For example, when we think of the behavior of maintaining social 
distancing, we have feelings in regard to what we think. In the same way, when we feel something in relation to maintaining social distancing, we think about these feelings. In the studied sample, we verified that beliefs with affective content were more consistent as measures of attitude in regard to social distancing. This may represent how much social distancing is mobilizing affective aspects in the lives of people living through this pandemic.

The excluded items SN3 and SN6 represent normative beliefs related to the motivation to cede to perceived social pressure, with motivation being an underlying facet of subjective norms. In the IMSDS there were items which referred specifically to the perception of social pressure (SN1, SN2, SN4, SN5) and items which referred to the individual motivation to cede to social pressure. The exclusion of the items related to motivation suggest that these measures are not effectively correlated with the subjective norm dimension in regard to social distancing behavior. The Latin origin of the word "motivation" signifies "to move" and in this way it is broadly understood in common usage. However, the scientific significance of "motivation" is the study of an action and its relationship with beliefs, values, goals and objectives (Eccles \& Wigfield, 2002). Even though it has this scientific significance, the popular perception of the term is broader and it is possible that the intended meaning was not understood by the respondents.

The excluded items PBC2, PBC3 and PBC6 represent respectively control beliefs related to perceived difficulty (easy/difficult), financial control (have enough money) and self-efficacy (if I wished). The remaining items ( $\mathrm{PBC} 1, \mathrm{PBC} 4, \mathrm{PBC} 5)$ are related to the perception of self-efficacy in terms of the adoption of social distancing. It should be noted that the indices obtained in the factor analysis of the remaining items of the perceived behavioral control dimension were the ones which presented less commonality, which may be associated with the fact that social distancing is a new recommendation for the population. The participants are probably experiencing the need to adopt this type of behavior for the first time and do not have previous experience which can serve as a parameter to gauge impeding or facilitating factors related to the performance of this behavior.

Items INT4 and INT5 present cross-loading in the attitude and intention to maintain social distancing dimensions. To a certain extent, theoretically there was an expectation of the existence of some degree of correlation between the factor dimensions attitudes and intention to maintain social distancing, and it is also possible that the behavioral beliefs related to the attitude dimension are correlated with the beliefs regarding intention. Assuming the existence of collinearity between these dimensions, we utilized the promax oblique rotation in the explanatory factor analysis (Hair et al., 2009). After the exclusion of items INT4 and INT5, the remaining items consolidated into a factor dimension with greater internal consistency.

After the exclusion of the items one by one, a new inspection was performed. This process was realized until the problems of cross-loading were resolved and the factor loading presented acceptable values (>0.50). The reliability analysis of the group of items, evaluated by Cronbach's alpha, also demonstrated acceptable values $(\alpha>0.70)$. The final factor solution obtained may be observed in Table 2. 


\section{TABLE 2 EXPLORATORY FACTOR ANALYSIS}

\begin{tabular}{|c|c|c|c|c|c|}
\hline ITEM & Factor 1 & Factor 2 & Factor 3 & Factor 4 & $h^{2}$ \\
\hline $\begin{array}{l}\text { SN4 - The majority of the people who are important to me think } \\
\text { that I should maintain social distancing for the next few days. }\end{array}$ & 0.96 & & & & 0.83 \\
\hline $\begin{array}{l}\text { SN5 - People whose opinion I value would like me to maintain } \\
\text { social distancing for the next few days. }\end{array}$ & 0.92 & & & & 0.83 \\
\hline $\begin{array}{l}\text { SN2 - The majority of the people who are important to me would } \\
\text { like me to maintain social distancing for the next few days. }\end{array}$ & 0.89 & & & & 0.76 \\
\hline $\begin{array}{l}\text { SN1 - People whose opinion I value approve of my decision to } \\
\text { maintain social distancing for the next few days. }\end{array}$ & 0.54 & & & & 0.60 \\
\hline INT3 - I will maintain social distancing for the next few days. & & 1.05 & & & 0.87 \\
\hline INT6 - I would maintain social distancing for the next few days. & & 0.94 & & & 0.85 \\
\hline INT2 - I plan to maintain social distancing for the next few days. & & 0.80 & & & 0.84 \\
\hline INT1 - I intend to maintain social distancing for the next few days. & & 0.63 & & & 0.83 \\
\hline $\begin{array}{l}\text { ATT6 - Maintaining social distancing for the next few days will } \\
\text { make me feel calm. }\end{array}$ & & & 0.98 & & 0.78 \\
\hline $\begin{array}{l}\text { ATT2 - Maintaining social distancing for the next few days will } \\
\text { make me feel well. }\end{array}$ & & & 0.75 & & 0.62 \\
\hline $\begin{array}{l}\text { ATT4 - Maintaining social distancing for the next few days will } \\
\text { make me feel safe. }\end{array}$ & & & 0.61 & & 0.77 \\
\hline $\begin{array}{l}\text { PBC4 - I believe that maintaining social distancing just depends on } \\
\text { my decision and not on external conditions. }\end{array}$ & & & & 0.88 & 0.51 \\
\hline $\begin{array}{l}\text { PBC1 - I consider maintaining social distancing for the next few } \\
\text { days to be something that just depends on my will. }\end{array}$ & & & & 0.76 & 0.44 \\
\hline $\begin{array}{l}\text { PBC5 - I am confident that, if I wish, I can decide to maintain social } \\
\text { distancing for the next few days. }\end{array}$ & & & & 0.53 & 0.43 \\
\hline Eigenvalue & 8.14 & 1.88 & 0.91 & 0.74 & \\
\hline Explained Variance (\%) & 58.18 & 13.45 & 6.47 & 5.26 & \\
\hline Number of Items & 4 & 4 & 3 & 3 & \\
\hline Cronbach's Alpha & 0.93 & 0.96 & 0.90 & 0.78 & \\
\hline
\end{tabular}

Source: Primary Data (2020). 
The final factor solution presented an excellent average KMO (0.92), and the Bartlett sphericity test demonstrated the rejection of the null hypothesis, which confirms the appropriateness of the sample for the application of factor analysis $\left[\chi^{2}(91)=10,816.67, p<0.00\right]$. The final solution indicated a structure with four dimensions, with accumulated explanatory variance of $81.36 \%$.

The IMSDS obtained is composed of fourteen items, distributed in four dimensions. Factor 1 (subjective norms) is composed of four items which accounted for $56.18 \%$ of the variability of the data ( $\alpha=0.93$ ). Factor 2 (intention to maintain social distancing) is composed of four items which account for $13.45 \%$ of the variability of the data $(\alpha=0.96)$. Factor 3 (attitudes) is composed of three items which account for $6.47 \%$ of the variability of the data $(\alpha=0.90)$. Factor 4 (perceived behavioral control) is composed of three items which account for $5.26 \%$ of the variability of the data $(\alpha=0.78)$.

Using the group of items which constitute each factor, we calculated the variables: attitudes, subjective norms, perceived behavioral control, and intention to maintain social distancing. The value attributed to the variables should correspond respectively to the arithmetic average of the items within each factor dimension (Hair et al., 2009). The minimum, maximum, and average values and the standard deviation of the variables may be observed in Table 3.

\section{TABLE $3 \quad$ INDICES OF THE DISPERSION OF THE VARIABLES}

\begin{tabular}{lcccc}
\multicolumn{5}{c}{ INDICES OF THE DISPERSION OF THE VARIABLES } \\
Variables & Minimum & Maximum & Average & Stand. Deviation \\
\hline 1. Attitudes & 1.00 & 7.00 & 5.75 & 1.64 \\
2. Subjective Norms & 1.00 & 7.00 & 6.20 & 1.31 \\
3. Perceived Behavioral Control & 1.00 & 7.00 & 3.97 & 1.75 \\
4. IMSD & 1.00 & 7.00 & 6.16 & 1.52
\end{tabular}

Source: Primary Data (2020).

The average of the intention to maintain social distancing (6.16) suggests that the sample concentrates participants who are highly inclined to adopt this measure. The average of subjective norms (6.20) indicates that the participants feel highly pressured to maintain social distancing. The average of attitudes (5.75) demonstrates that the participants are also in favor of social distancing, while the average of perceived behavioral control (3.97) suggests that the perception of participants' control is distributed in a more heterogeneous manner. The results indicate that the participants present a greater probability of adopting social distancing, possibly due to the sample not being probabilistic, which does not guarantee that each element of the Brazilian population has an equal chance of being included in the sample (Shaughnessy et al., 2012). It is possible that people more inclined to maintain social distancing or who have already adopted the measure felt more motivated or were more available to answer the survey. 


\subsection{Analysis of the hierarchical multiple linear regression}

The technique of hierarchical multiple regression was used to verify whether the variables attitudes, subjective norms and perceived behavioral control predict the intention to maintain social distancing. The three independent variables were included one by one, generating three models. A fourth model was also tested to verify the possible effects of the sociodemographic variables. The outlier analysis identified sixty cases of residual values with discrepancies, which were excluded from the analysis. The used sample thus consisted of 726 participants. All of the assumptions for performing the regression were met. The summary of the tested models can be seen below in Table 4 .

\section{TABLE 4 SUMMARY OF THE TESTED MODELS}

\begin{tabular}{|c|c|c|c|c|c|c|c|c|c|}
\hline \multicolumn{10}{|c|}{ SUMMARY OF THE TESTED MODELS } \\
\hline \multirow{2}{*}{ Model } & \multirow{2}{*}{ R } & \multirow{2}{*}{$\mathrm{R}^{2}$} & \multirow{2}{*}{ Adjusted $\mathrm{R}^{2}$} & \multirow{2}{*}{$\begin{array}{c}\text { Standard } \\
\text { Error }\end{array}$} & \multicolumn{5}{|c|}{ Change statistics } \\
\hline & & & & & Change in $\mathrm{R}^{2}$ & Change $\mathrm{F}$ & df1 & df2 & $\mathrm{p}$-value \\
\hline 1 & 0.81 & 0.65 & 0.65 & 0.79 & 0.65 & $1,342.47$ & 1.00 & 724 & 0.00 \\
\hline 2 & 0.92 & 0.84 & 0.84 & 0.53 & 0.19 & 856.66 & 1.00 & 723 & 0.00 \\
\hline 3 & 0.92 & 0.84 & 0.84 & 0.53 & 0.00 & 16.52 & 1.00 & 722 & 0.00 \\
\hline 4 & 0.92 & 0.85 & 0.85 & 0.52 & 0.01 & 4.14 & 6.00 & 716 & 0.00 \\
\hline
\end{tabular}

Notes:

Model 1: (Constant), Attitudes.

Model 2: (Constant), Attitudes, Subjective Norms.

Model 3: (Constant), Attitudes, Subjective Norms, Perceived Behavioral Control

Model 4: (Constant), Attitudes, Subjective Norms, Perceived Behavioral Control, Age Group, Income, Education, Occupation, Biological Sex, Marital Status.

Dependent Variable: Intention to Maintain Social Distancing.

Source: Primary Data (2020).

The analysis resulted in a statistically significant model $\left[\mathrm{F}(10,715)=401.51, \mathrm{p}<0.00, \mathrm{R}^{2}=0.85\right.$, Adjusted $\left.\mathrm{R}^{2}=0.85\right]$. Attitudes $(\beta=0.24, \mathrm{t}=10.17, \mathrm{p}<0.00)$, subjective norms $(\beta=0.69, \mathrm{t}=28.82$, $\mathrm{p}<0.00)$ and the perceived behavioral control $(\beta=0.07, \mathrm{t}=4.29, \mathrm{p}<0.00)$ are predictors of the intention to maintain social distancing. All of the hypotheses $(\mathrm{H} 1, \mathrm{H} 2$ and $\mathrm{H} 3)$ postulated in this study were confirmed. The TPB variables explained $85 \%$ of the variation in the intention to maintain social distancing. Hierarchically attitudes contributed to $65 \%$ of the total variance explained by the model, subjective norms contributed $19 \%$, perceived behavioral control $0.4 \%$, and the sociodemographic variables contributed $0.5 \%$.

The increase in sociodemographic variables revealed that the variables age group $(\beta=-0.07$, $\mathrm{t}=-3.79, \mathrm{p}<0.00)$, income $(\beta=0.04, \mathrm{t}=2.22, \mathrm{p}<0.03)$ and education $(\beta=0.04, \mathrm{t}=1.98, \mathrm{p}<0.05)$ are predictors of the intention to maintain social distancing. However, the variables occupation $(\beta=-0.03, \mathrm{t}=-1.87, \mathrm{p}<0.06)$, biological sex $(\beta=-0.01, \mathrm{t}=-0.85, \mathrm{p}<0.40)$ and marital status $(\beta=-0.01, \mathrm{t}=-0.46, \mathrm{p}<0.65)$ did not present an effect, considering a level of significance of $95 \%$. 
The effect of sociodemographic variables was considered small $(\beta \leq 0.20)$. The interpretation of the regression coefficients ( $\beta$ ) followed Cohen's criteria (1992): small $(\beta \geq 0.20)$, medium $(\beta \geq 0.50)$ and large $(\beta \geq 0.70)$. The non-standardized $(B)$ and standardized $(\beta)$ coefficients and the significance test of the tested models are presented in Table 5 .

\section{TABLE 5 COEFFICIENTS AND THE SIGNIFICANCE TEST}

\begin{tabular}{|c|c|c|c|c|c|}
\hline \multicolumn{6}{|c|}{$\begin{array}{l}\text { NON-STANDARDIZED (B) AND STANDARDIZED ( } \beta \text { ) COEFFICIENTS } \\
\text { AND THE SIGNIFICANCE TEST }\end{array}$} \\
\hline Models & B & $\begin{array}{l}\text { Standard } \\
\text { Error }\end{array}$ & $\beta$ & $T$ & $\mathrm{p}$-value \\
\hline \multicolumn{6}{|l|}{ Model 1} \\
\hline (Constant) & 2.33 & 0.11 & & 20.56 & 0.00 \\
\hline Attitudes & 0.68 & 0.02 & 0.81 & 36.64 & 0.00 \\
\hline \multicolumn{6}{|l|}{ Model 2} \\
\hline (Constant) & 0.37 & 0.10 & & 3.69 & 0.00 \\
\hline Attitudes & 0.21 & 0.02 & 0.25 & 10.18 & 0.00 \\
\hline Subjective Norms & 0.75 & 0.03 & 0.71 & 29.27 & 0.00 \\
\hline \multicolumn{6}{|l|}{ Model 3} \\
\hline (Constant) & 0.28 & 0.10 & & 2.75 & 0.01 \\
\hline Attitudes & 0.20 & 0.02 & 0.24 & 9.74 & 0.00 \\
\hline Subjective Norms & 0.74 & 0.03 & 0.70 & 29.23 & 0.00 \\
\hline Perceived Behavioral Control & 0.05 & 0.01 & 0.06 & 4.06 & 0.00 \\
\hline \multicolumn{6}{|l|}{ Model 4} \\
\hline (Constant) & 0.34 & 0.12 & & 2.78 & 0.01 \\
\hline Attitudes & 0.21 & 0.02 & 0.24 & 10.17 & 0.00 \\
\hline Subjective Norms & 0.73 & 0.03 & 0.69 & 28.82 & 0.00 \\
\hline Perceived Behavioral Control & 0.05 & 0.01 & 0.07 & 4.29 & 0.00 \\
\hline Age group & -0.08 & 0.02 & -0.07 & -3.79 & 0.00 \\
\hline Income & 0.04 & 0.02 & 0.04 & 2.22 & 0.03 \\
\hline Education & 0.04 & 0.02 & 0.04 & 1.98 & 0.05 \\
\hline Occupation (1, with occupation; 0 , without occupation) & -0.09 & 0.05 & -0.03 & -1.87 & 0.06 \\
\hline Biological Sex (1, female; 0 , male) & -0.03 & 0.04 & -0.01 & -0.85 & 0.40 \\
\hline Marital Status (1, Single; 0, other) & -0.02 & 0.05 & -0.01 & -0.46 & 0.65 \\
\hline
\end{tabular}

Note: Adjusted $\mathrm{R}^{2}=0.65$ for Model $1 ; \Delta \mathrm{R}^{2}=0.19$ for Model 2; $\Delta \mathrm{R}^{2}=0.004$ for Model $3 ; \Delta \mathrm{R}^{2}=0.005$ for Model 4 . Source: Primary Data (2020). 
The attitudes and subjective norms presented large correlations $(r>0.50)$ with the intention to maintain social distancing, while perceived behavioral control presented a medium correlation (0.30). Attitudes and subjective norms also presented a large correlation between each other (0.79), while the correlations among attitudes and subjective norms and perceived behavioral control were small $(r<0.30)$. The interpretation of the correlation coefficients $(r)$ was performed using Cohen's criterion: (1992): $r \geq 0.10$ (weak), $r \geq 0.30$ (medium) and $r \geq 0.50$ (strong). The correlations among the variables may be observed in Table 6 .

\section{TABLE 6 VARIABLE CORRELATION MATRIX}

\begin{tabular}{|c|c|c|c|c|}
\hline \multicolumn{5}{|c|}{ VARIABLE CORRELATION MATRIX } \\
\hline Variables & 1 & 2 & 3 & 4 \\
\hline 1. Attitudes & 1.00 & & & \\
\hline 2. Subjective Norms & $0.79^{*}$ & 1.00 & & \\
\hline 3. Perceived Behavioral Control & $0.27^{\star}$ & $0.25^{*}$ & 1.00 & \\
\hline 4. Intention to Maintain Social Distancing & $0.80^{*}$ & $0.90^{*}$ & $0.30^{*}$ & 1.00 \\
\hline
\end{tabular}

Note: ${ }^{\star} \mathrm{p}<0,00$.

Source: Primary Data (2020)

By virtue of the found correlations, we can say that attitudes and subjective norms present a portion of the shared explanatory variance in the intention to maintain social distancing, while perceived behavioral control better explains a portion of the intention's own variance, as displayed in Table 5. In Model 2, with the addition of subjective norms, attitudes displayed a reduced effect. In Model 3, the addition of perceived behavioral control did not interfere with the effect of the attitudes and subjective norms.

\section{DISCUSSION}

The goal of this study is to develop an IMSDS based on TPB, widely used in studies in the areas of Health and Human Sciences. The meta-analysis of Armitage and Conner (2001) presents evidence in terms of the effectiveness of the use of TPB in various contexts, with an average explanation of $39 \%$ of the variance in intention. The model employed here explained $85 \%$ of the IMSD variation, demonstrating that the TPB is effective in explaining the formation of this intention. Through the relative weight of each predictor (attitudes, subjective norms and perceived behavioral control) of IMSD, we can predict the behavior of maintaining social distancing and, mainly plan interventions for this purpose.

The subjective norms variable related to the perception of social pressure put on people by their peers, was the predictor which most influenced the formation of the IMSD in this study. Or in other words, the more that individuals perceive that people important to them think they should maintain 
social distancing, the more likely they will be to acquiesce to this social pressure. The perception of personal advantages associated with maintaining social distancing (positive attitudinal beliefs), such as well-being and safety, also influenced the formation of the IMSD. The adding of the perceived behavioral control predictor improved the model's fit, even though its effect was close to zero $(\beta=0.06)$. The same can be said about the effect of including sociodemographic variables in the model.

The results of this study are relevant to public and private organizations involved in the combat against COVID-19, because they demonstrate that beliefs of normative and attitudinal content have large and medium effects on the intention to maintain social distancing. That being so, they are useful in the elaboration of strategies to promote the maintenance of social distancing. These results offer a conceptual framework and reinforce the proposals of Van Bavel et al. (2020) about possible responses that the social sciences can offer to the COVID-19 pandemic.

According to Van Bavel et al. (2020), identifying credible key figures (e.g. religious or political leaders) can be an effective strategy to disseminate persuasive messages of public health campaigns during epidemics. These authors point out that during the Ebola crisis in West Africa the engagement of religious leaders who espoused best practices was considered to be a turning point in the response to the epidemic.

Van Bavel et al. (2020) also indicate that leaders should reinforce their support, free from politicalparty associations, of COVID-19 measures - in cases where disagreements occur - because this endorsement reduces the political polarization associated with the subject and helps promote these measures. Van Bavel et al. (2020) stress that the messages should seek to emphasize: a) the benefits to the target audience (e.g. self-protection); b) behavior as a social protection measure; c) normative appeals (e.g. "the overwhelming majority of people in your community believe that everyone should stay at home"); and d) this behavior as something expected by social groups.

An analysis of these recommendations, based on TPB, indicates that leaders act as significant people capable of stimulating social pressure for the performance of a behavior. Therefore, they stimulate subjective norms that pressure people to behave in a specific way. As the results of this study show, subjective norms and positive attitudes related to social distancing are correlated, and for this reason these leaders are doubly important. They have the power and legitimacy to disseminate favorable information about the target behavior. Or in other words, they influence the formation of subjective norms and attitudes, exactly the two variables with greatest force in the formation of the intention to maintain social distancing.

Given this, the ideal scenario would be a unanimous discourse presented to the population by political, religious, artistic, social, and digital figures who occupy leadership roles. However, the scenario of political polarization which currently exists in Brazil not only strengthens the level of discord between the presented discourses, it also treats issues of public health as a clash of party ideals, devoid of the evidence necessary to justify their actions.

Ajzenman, Cavalcanti, and Da Mata (2020) reveal alarming results in relation to the impact of the anti-isolation discourse propagated by President Bolsonaro about individual behavior. The researchers combined electoral and mobile telephone geographic data for more than 60 million devices all over the country. The evidence found by the researchers indicates that the indices of social distancing in pro-government areas diminished significantly after the President of Brazil publicly and emphatically belittled the risks associated with COVID-19. 
This raises the hypothesis that political-party orientation exercises an effect on the intention to maintain social distancing. This influence was confirmed by the study of Allcott et al. (2020). According to these authors, the content of messages from political leaders and the main sources of communication about the gravity of the COVID-19 pandemic have substantially affected how American citizens respond to the situation. The authors also point out that political-party issues between Republicans and Democrats in the United States have not brought positive results for either of these sides. The lack of a consensus among these discourses concerning how to combat the pandemic has generated conflicts and disinformation, which hinders the fight against the disease and potentially will generate greater economic costs, contrary to what would happen if both sides of the political aisle adopted the same beliefs and same discourse of public awareness (Allcott et al., 2020).

In Brazil, a study by Farias and Pilati (2020) demonstrates the effect of political partisanship on the intention to violate the measure of social distancing. Online research by the researchers featured the participation of 2,056 Brazilians (a non-probabilistic sample). According to Farias and Pilati (2020), people who support President Bolsonaro have greater intentions to violate social distancing. As the authors point out, Bolsonaro is seen in Brazil as an extreme right-wing conservative who has positioned himself vehemently against social distancing, alleging that this measure would have a negative impact on the economy. As a result, people who share his party identity tend to support him and question the adoption of this measure. Within this context, Farias and Pilati (2020) agree with Van Bavel et al. (2020) about the importance of reducing the political polarization associated with the actions being taken to combat the pandemic.

This study specifically investigates the effect that the original predictors of TPB (attitudes, subjective norms, and perceived behavioral control) exercise on the formation of the intention to maintain social distancing. Various studies use the TPB as a reference model, proposing extensions to the model with the addition of new constructs, a practice recommended by Ajzen (1991), with the goal of observing whether the addition of new constructs will increase its predictive capacity. However, it is most recommended to test the TPB model with its original variables, verifying whether they explain or do not explain a significant portion of the variance in intention.

In this way, the evidence presented by Allcott et al. (2020) and Farias and Pilati (2020) suggest that the addition of a construct associated with political-party orientation as a possible predictor of the adoption of social distancing, could be considered for future studies. Other variables with predictive potential could be associated with the perception of cases of, and the damaging consequences of, the disease such as knowing someone who: a) has been infected by the virus; $b$ ) who has continued to suffer from respiratory damage after contracting the disease; c) and/or has died from the virus. Studies which investigate these perceptions have still not been published in Brazil.

The authors recommend that future studies which use the IMSDS apply it integrally, also reintegrating the items which were excluded in the exploratory factor analysis, verifying possible variations due to the application of the integral scale in other samples with people in different circumstances and/or contexts. We also recommend a second study which applies structural equation modeling techniques, verifying the robustness of the instrument and realizing analyses of the measurement and structural models.

Future studies also can weigh the viability of: a) using other ways of delineating the research (experimental and/or longitudinal); b) incorporating a measure of real behavior; c) using representative 
and/or stratified sample approaches; d) verifying differences in participant responses when the adoption of the measure has been established for an indefinite amount of time. The last suggestions are intrinsically linked to the methodological limitations presented in this section.

To conclude, this study constitutes an initial effort to construct an IMSDS, anchored on the assumptions of TPB, which has contributed to the understanding of the effectiveness of the IMSDS in measuring potential constructs in a reproducible and reliable manner. The developed scale presents acceptable psychometric properties and can be utilized as an instrument to measure the intention of people to follow the practice of social distancing in Brazil.

This study also supplies relevant information about which beliefs have greater effects as predictors of the intention to maintain social distancing. We have found that subjective norms related to perceived social pressure have a strong influence on the intention to maintain social distancing. The attitudes related to the perception of advantages (e.g. well-being, safety) also exercise a moderate influence on the intention to maintain social distancing. This information can be considered by public and private organizations in the elaboration of persuasive communication strategies regarding the dissemination of the practice of social distancing.

\subsection{Limitations}

Like every study, this one also has methodological limitations. Fishbein and Ajzen (2010) establish two main categories of limitations related to studies which use TPB as a predictive model of intention: a) limitations related to the validity of the constructs through a delineation of the research; and b) limitations related to the use of correlated data in the testing of causal effects.

Critiques associated with the delineation of research are mainly due to the utilization of self-reported measures, which may present consistent biases related to social desirability and result in overestimated correlations between the theoretical components. In terms of the limitation related to the use of correlated data for testing causal effects, Fishbein and Ajzen (2010) comment that correlated data can be partially interpreted with (predictive) causal effect evidence, given the robust evidence which supports the TPB.

The non-probabilistic sample and the online collection of data also imply limitations. The sample used in this study cannot be considered representative of the Brazilian population, and for this reason its results cannot be generalized and its interpretation should be treated with caution. The observation of the sociodemographic data demonstrates that the sample presents a selection bias, with the super-representation of one segment of the population (for example, $48 \%$ of the participants were from the 18 to 27 age group, $58.90 \%$ of the participants had college education or above, and $88 \%$ of the participants lived in the southern region of Brazil).

Another limitation has to do with the question adopted to triage the participants ("Are you at least 18 years old and belong to the group of people who can maintain social distancing?"), whose potential to generate response biases leads participants to reflect whether they can adhere to this behavior, while other people do not have this option. This limitation could be addressed by presenting the triage question at the end of the survey.

Studies have demonstrated that the subjective evaluation of attributes associated with behavior can vary by virtue of the perceived temporal distance between the formulation of the intention and 
RAP | Predictors of the intention to maintain social distancing

the real behavior (Ajzen, 1985). The evaluation of beliefs about the adoption of social distancing should also consider the perception of how long this situation will last. This study has evaluated the intention to maintain social distancing "for the next few days." If the perception of the duration of time during which this measure of social distancing needs to be adopted were altered (e.g. "while requested by the appropriate government bodies"), there would certainly be changes in the patterns of the participants' responses. 


\section{REFERENCES}

Abraham, C., \& Sheeran, P. (2003). Acting on intentions: the role of anticipated regret. British Journal of Social Psychology, 42(4), 495-511. Retrieved from http://doi.org/10.1348/014466603322595248

Ajzen, I. (1985). From intentions to actions: a theory of planned behavior. In J. Kuhl, \& J. (Eds), Action Control (SSSP Springer Series in Social Psychology, pp. 11-39). Berlin, Germany: Heidelberg. Retrieved from https://link.springer. com/chapter/10.1007/978-3-642-69746-3_2

Ajzen, I. (1991). The theory of planned behavior. Organizational behavior and human decision processes, 50(2), 179-211. Retrieved from http://doi. org/10.1016/0749-5978(91)90020-T

Ajzen, I., \& Cote, N. G. (2008). Attitudes and the prediction of behavior. In W. D. Crano, \& R. Prislin (Eds.), Attitudes and attitude change (pp. 289-311). New York, NY: Psychology Press.

Ajzen, I. (2011). The theory of planned behaviour: reactions and reflections. Psychology \& Health, 26(9), 1113-1127. Retrieved from http://doi.org/10.1080/0 8870446.2011 .613995

Ajzen, I. (2015). The theory of planned behaviour is alive and well, and not ready to retire: a commentary on Sniehotta, Pressau, and Araújo-Soares. Health Psychology Review, 9(2), 131-137. Retrieved from http://doi.org/10.1080/17437199.2014.883474

Ajzenman, N., Cavalcanti, T., \& Da Mata, D. (2020, April 23). More than words: leaders' speech and risky behavior during a pandemic. SSRN. Retrieved from http://dx.doi.org/10.2139/ssrn.3582908

Allcott, H., Boxell, L., Conway, J. C., Gentzkow, M., Thaler, M., \& Yang, D. Y. (2020, April). Polarization and public health: Partisan differences in social distancing during the Coronavirus pandemic (Working Paper n. 26946). National Bureau of Economic Research. SSRN. Retrieved from https:// ssrn.com/abstract $=3574415$

Armitage, C. J., \& Conner, M. (2001). Efficacy of the theory of planned behaviour: a metaanalytic review. British journal of social psychology, 40(4), 471-499. Retrieved from https://doi. org/10.1348/014466601164939

Barros-Delben, P., Cruz, R. M., Trevisan, K.R. R., Gai, M. J. P., Carvalho, R. V. C., Carlotto,
P. A. C. ... Malloy-Diniz, L. F. (2020, June). Saúde mental em situações de emergência: COVID-19. Revista Debates in Psiquiatria, Ano 10(2), 18-28. Retrieved from https://d494f8133c95-463a-898c-ea1519530871.filesusr.com/ugd/ c37608_6bd285d2f02b40098a94c81c49d603b8.pdf

Castillo, C., Macrini, L., Cheniaux, E., \& LandeiraFernandez, J. (2010). Psychometric properties and latent structure of the Portuguese version of the Penn State Worry Questionnaire. The Spanish journal of psychology, 13(1), 431-443. Retrieved from https:// doi.org/10.1017/S113874160000398X

Chaves, T. S. S., \& Bellei, N. (2020). SARS-CoV-2, o novo Coronavírus: uma reflexão sobre a Saúde Única (One Health) e a importância da medicina de viagem na emergência de novos patógenos. Revista de Medicina, 99(1), 1-4. Retrieved from http://dx.doi. org/10.11606/issn.1679-9836.v99i1pi-iv

Cohen, J. (1992). A power primer. Psychological Bulletin, 112(1), 155-159. Retrieved from https:// doi.org/10.1037/0033-2909.112.1.155

Cohen, R. J., Swerdlik, M. E., \& Sturman, E. D. (2014). Testagem e Avaliação Psicológica: introdução a teste e medidas. Porto Alegre, RS: Artmed.

Damásio, B. F. (2012). Uso da análise fatorial exploratória em psicologia. Avaliação Psicológica, 11(2), 213-228. Retrieved from https:// pepsic.bvsalud.org/pdf/avp/v11n2/v11n2a07.pdf

Draugalis, J. R., Coons, S. J., \& Plaza, C. M. (2008). Best practices for survey research reports: A synopsis for authors and reviewers. American Journal of Pharmaceutical Education, 72(1), 1-6. Retrieved from https://doi.org/10.5688/aj720111

Eccles, J. S. \& Wigfield, A. (2002). Motivational beliefs, values, and goals. Annual Review of Psychology, 53(1), 109-132. Retrieved from https:// doi.org/10.1146/annurev.psych.53.100901.135153

Farias, J. E. M., \& Pilati, R. (2020, April 29). Violating social distancing amid COVID-19 pandemic: psychological factors to improve compliance. PsyArXiv Preprints. Retrieved from https://doi. org/10.31234/osf.io/apg9e

Ferguson, N., Laydon, D., Nedjati Gilani, G., Imai, N., Ainslie, K., Baguelin, M. ... Dighe, A. (2020, March 16). Report 9: Impact of non- 
pharmaceutical interventions (NPIs) to reduce COVID-19 mortality and healthcare demand. London, UK: Imperial College. Retrieved from https://doi.org/10.25561/77482

Fishbein, M., \& Ajzen, I. (2010). Predicting and changing behavior: the reasoned action approach. New York, NY: Psychology Press. Retrieved from https://doi.org/10.4324/9780203838020

Francis, J., Eccles, M. P., Johnston, M., Walker, A. E., Grimshaw, J. M., Foy, R. ... Bonetti, D. (2004). Constructing questionnaires based on the theory of planned behaviour: a manual for health services researchers. Newcastle upon Tyne, UK: Centre for Health Services Research, University of Newcastle upon Tyne. Retrieved from http://openaccess.city. ac.uk/1735/

Hagger, M. S., Hamilton, K., Ajzen, I., Bosnjak, M., \& Schmidt, P. (2019, November). Testing the replicability of the Theory of Planned Behavior: a large-scale multi-sample registered replication study. Trier, German: Leibniz Institut für Psychologische Information und Dokumentation [ZPID]. Retrieved from http://dx.doi.org/10.23668/psycharchives.2652

Hair, J. F., Black, W. C., Babin, B. J., Anderson, R. E., \& Tatham, R. L. (2009). Análise multivariada de dados. Porto Alegre, RS: Bookman.

Lana, R. M., Coelho, F. C., Gomes, M. F. D. C., Cruz, O. G., Bastos, L. S., Villela, D. A. M., \& Codeço, C. T. (2020). Emergência do novo coronavirus (SARS-CoV-2) e o papel de uma vigilância nacional em saúde oportuna e efetiva. Cadernos de Saúde Pública, 36(3), 1-5. Retrieved from https://doi. org/10.1590/0102-311X00019620

Leeuw, A., Valois, P., Ajzen, I., \& Schmidt, P. (2015). Using the theory of planned behavior to identify key beliefs underlying pro-environmental behavior in high-school students: implications for educational interventions. Journal of Environmental Psychology, 42(1), 128-138. Retrieved from https:// doi.org/10.1016/j.jenvp.2015.03.005

Pasquali, L. (2005). Análise fatorial para pesquisadores. Brasília, DF: LabPAM.

Pereira, C. D. A., Maciel, S. C., Dias, C. C. V., Alexandre, T. M. D. O., Oliveira, M. X. D., \& Pimentel, C. E. (2019). Validação da Escala de Crenças sobre Abuso Sexual (ECAS) no contexto brasileiro. Psico-USF, 24(1), 145-158. Retrieved from https://doi.org/10.1590/1413-82712019240112

Schleicher D. J., Watt J. D., \& Greguras G. J. (2004). Reexamining the job satisfaction-performance relationship: the complexity of attitudes. Journal of applied psychology, 89(1), 165-77. Retrieved from https://doi.org/10.1037/0021-9010.89.1.165

Shaughnessy, J. J., Zechmeister, E. B., \& Zechmeister, J. S. (2012). Metodologia de pesquisa em psicologia. Porto Alegre, RS: AMGH.

Steil, A. V., Floriani, E. V., Zilli, M., \& Rubio, M. A. (2019). Intenção de sair da organização: definições, métodos e citações em publicações nacionais. Revista Psicologia: Organizações e Trabalho, 19(2), 580-587. Retrieved from https://doi.org/10.17652/ rpot/2019.2.14080

Steinmetz, H.; Knappstein, M.; Ajzen, I., Schmidt, P.; \& Kabst, R. (2016). How effective are behaviour change interventions based on the theory of planned behaviour? A three level meta-analysis. Zeitschrift für Psychologie, 224(3), 2016-233. Retrieved from https://doi.org/10.1027/2151-2604/a000255

Van Bavel, J. J., Baicker, K, Boggio, P., Capraro, V., Cichocka, A., Crockett, M., ... Willer, R. (2020, March 24). Using social and behavioural science to support COVID-19 pandemic response. PsyArXiv Preprints. Retrieved from https://doi.org/10.31234/ osf.io/y38m9 


\section{Gabriel Horn Iwaya}

https://orcid.org/0000-0002-1075-9294

Ph.D. Student in Psychology at the Federal University of Santa Catarina (UFSC).

E-mail: gabrieliwaya@hotmail.com

\section{Janaína Gularte Cardoso}

https://orcid.org/0000-0002-2017-1304

Adjunct Professor in the Administration Program at the Federal University of the Southern Frontier (UFFS); Ph.D. Student in the Graduate Program in Administration at the Federal University of Santa Catarina; Marketing and Logistics Researcher in the CNPq Research Group at the Organizational Competitive Intelligence Center (NICO/UFSC). E-mail: janaina.cardoso@uffs.edu.br

\section{João Henriques de Sousa Júnior}

https://orcid.org/0000-0001-8589-8101

Ph.D. Student in Administration at the Federal University of Santa Catarina (UFSC); Master's in Administration from the Federal University of Pernambuco (UFPE); Specialist in Public Management at the Federal Institute of Pernambuco (IFPE); BA in Administration from the Federal University of Pernambuco (UFPE); Marketing and Logistics Researcher in the CNPq Research Group at the Organizational Competitive Intelligence Center (NICO/UFSC). E-mail: sousajunioreu@hotmail.com

\section{Andrea Valéria Steil}

https://orcid.org/0000-0001-7853-6532

Associate Professor in the Department of Psychology in the Graduate Programs of Psychology and Engineering and Knowledge Management at the Federal University of Santa Catarina (UFSC); Leader of the CNPq Research Group of Organizational Knowledge, Learning and Memory (KLOM). E-mail: andrea.steil@ufsc.br 